\title{
Aims and Methods of Civic Education in Today's Universities of China
}

\author{
Ping Xiao \\ School of Public Administration, Southwest Jiaotong University \\ $111,2^{\text {nd }}$ Ring Road North, Chengdu 610031, China \\ Tel: 86-28-8760-3848Ｅ-mail: pxiao008@gmail.com \\ Huasheng Tong \\ School of Political Science, Southwest Jiaotong University \\ $111,2^{\text {nd }}$ Ring Road North, Chengdu 610031, China \\ Tel: 86-28-8760-0818Ｅ-mail: tonghuasheng@126.com
}

\begin{abstract}
Civic education, as a way to foster civic awareness and civic responsibilities and to shape good citizens, should permeate through the whole process of a person's socialization. At different stages of civic education, there should be corresponding educational aims, contents and methods consistent with the characteristics of different stages. For historical and cultural reasons, Chinese universities now have to complete the unfinished part of the contents of civic education which haven't been dealt with in high schools. Universities should, on the basis of professional knowledge and skills, have the civic education related to occupational regulations and professional ethics in specific professions. The main aim of civic education in universities is to improve the students' ability to independently judge the value and properly control their behavior and to achieve the aim, the system of content should be well designed and the teaching methods should also be employed properly.
\end{abstract}

Keywords: Civic education, University students, Aims, Methods, China

\section{Introduction}

In new China's education system, "civic education" is a new word. But in recent years, the concept has been frequently used in Mainland China. At the 17th CPC National Congress, President Hu Jintao said, "We need to step up education about citizenship and establish socialist concepts of democracy, the rule of law, freedom, equality, equity and justice" ${ }^{11}$, which shows that civic education has attracted the attention of Chinese top leaders now.

To achieve educational task of "civic education" in this era, we should first understand what "civic education" is. Secondly, we will reflect on the manifestations of the civic education in the educational system in our society (that is, the national education system) and the relationship between civic education and the traditional moral education. And then the paper puts forward the aims and contents of civic education in universities in the national education system, and also corresponding methods in accordance with the aims and contents.

In order to understand the essence of "civic education", we will employ the document analysis method and use for reference the relatively mature research findings on "civic education" of the scholars in foreign countries as well as in China. After understanding the characteristics of civic education in New China and the social reality of our reform and opening up by using the comparison approach, we put forward our points of view. The discussion of aims, contents and methods of civic education in university is involved in the related theories in pedagogics, psychology and behavioristics and also related to the theories of culturology, politics, value philosophy and ethics, like the theory of conflict and integration between the traditional cultural values and the present social values. The paper will analyze all these issues with a relatively broad theoretical perspective.

\section{Essence of civic education and its relation with traditional moral education}

In Cihai, "citizen" is defined as "a person with a certain nationality who enjoys the rights and undertakes the obligations according to the provisions of the constitution or laws in the country" ${ }^{2}$. In the same version of Cihai, 
"civic education" is defined as "the political and ideological education carried out by capitalist countries to train the citizens to meet the political needs of the bourgeoisie" ${ }^{3}$. As we can perceive, at the beginning of the period of reform and opening up, the concept of class is still deeply engraved in people's mind. Regardless of the old idea of "class struggle", we should say that civic education refers to the kind of education to train citizens to adapt to the need of political and legal values in a specific society.

In the West, for historical and cultural reasons, the concepts "citizen" and "civic education" are more widely used and they have determinate definitions. "Civic education can be defined as the acquisition of knowledge, skills, and dispositions that are needed for effective and responsible citizenship in a democratic society." ${ }^{4}$ And Kathleen Knight-Abowitz says, "Encompassing aspects of membership, identity, civic knowledge, civic values, dispositions, and civic skills, citizenship education is often narrowly defined as taking place in civics, government, and history classes. But citizenship education is far broader than civics; here, it is defined as any educational experience that promotes the growth of individuals in regard to their civic capacities. "

From the different definitions of "civic education", we can accurately understand the concept by a few points. First of all, civic education, like other kinds of education, is the process of socialization of individuals. Secondly, the aim of civic education, unlike that of knowledge impartment, is to train citizens in line with the needs of society. Thirdly, the contents determined by the aims of civic education are different from the contents of other kinds of education. The contents of civic education include the necessary civic knowledge, skills and dispositions needed by effective and responsible citizens, or more exactly, the aspects of membership, identity, civic knowledge, civic values, dispositions and civic skills, while in China the so-called civic education was once described as the history of revolutionary struggle, political ideology, national laws, culture and morality, etc. The content of education must vary with the cultural value of a given society, but its essence is targeted in the training of the citizens adapting to the political and social life in the country.

Over the years, the concept of "ideological and political education" has been used in Mainland China. Ideological and political education is somewhat similar to civic education in content, but in fact, there is an important difference between these two concepts. Li Ping and Zhong Minghua in Sun Yat-sen University say in an article that "civic education" is the historic transformation of our traditional moral education. They believe that civic education must satisfy three basic conditions: to treat a citizen's independent personality as the premise; to treat the unity of rights and obligations as the base; to treat the legitimacy as the bottom line. ${ }^{6}$ Therefore, in essence, civic education must be a kind of education on subjectivity and the basic education orientation should be the unity of rights and obligations.

In our opinion, "civic education" and traditional moral education are different in the following aspects. Firstly, civic education stresses the consciousness of an educatee's independent personality, which is involved in the choice of educational methods discussed a lot in ideological and political education and also in the great difference of educational ideas between these two concepts. Secondly, the traditional moral education was influenced by the planned economy, so its ideas, values, norms and many other contents can not meet the social demand of the market economy. Civic education emphasizes the concept of rule by law, the legal status of an educatee and the independent sense of rights and responsibilities, so it was adapted to the requirements of the market economy. Thirdly, the trend of social development is increasingly high level of socialization and increasingly sophisticated social division of labor, so people's professional activities play a more and more special role in people's life and the society expects higher and higher demands in people's professional activities. It is necessary to extend civic education to the professional training in higher education so that the professionals and technicians would meet the requirements of social values and social development when they enter the society. Finally, although civic education is certainly based on a country's political ideology and structure and legal and moral knowledge, yet the focus is the cultivation of civic dispositions and behavior patterns, which is different from the way of knowledge impartment in traditional moral education. Therefore, the educatees' independent judgment ability, rational spirit and good behavior control are all the focus of civic education, especially in the stage of higher education.

\section{Civic education aims in university}

Civic education is a continuous process of social education. In the process of civic education in schools and universities, the aims of civic education should vary according to the knowledge store and cognitive ability of students at different stages, and the corresponding contents of civic education should also be differentiated.

In the U.S.A., the main course for civic education in primary and secondary schools is Social Studies, which is to enhance students' necessary knowledge, attitudes and abilities for participation in public general affairs. And civic education in higher education is the extension of the training to foster the students' responsibilities and 
dispositions needed in their future professions. ${ }^{7}$

In Japan, the Teaching Program published in 1989 stressed the difference of education in different stages. The primary school is divided into three stages: Grades 1-2 focus on the training of basic living habits, Grades 3-4 focus on the attitude to obey the rules of living and Grades 5-6 focus on the cultivation of the spirit of compliance with social ethics and contribution to social public utilities. In 1989 revision Essentials of Learning Guide in High School - Ethics, the aims of moral education in high schools are as follows: "Based on Basic Education Law and the fundamental spirit of education under School Law, the spirit of respect for humanity and the idea of reverence for life should be embodied in realistic life in families, schools and communities. And we will educate such Japanese with subjectivity as can create an individualized culture, a democratic society and a developed country and contribute to a peaceful international community." 8

Moral education in China is also carried out step by step, and its main aim is to enable students to understand the civic knowledge, to cultivate a certain degree of civic capacity and to take initial shape of their own value system. Students are expected to learn about the basic rights and obligations of citizens, to understand their own government and the state, to get to know the traditional customs and historical culture, to learn about their physical function, to get familiar with their living environment, to understand and comply with daily codes of conduct and to develop good living and study habits. At the same time, students should also learn to be independent, to get along well with others, to care for others, to deal with stress rationally, to face bravely the setbacks, to undertake the obligations and to build positive values and attitudes towards life. Therefore, it is necessary for the students to learn about their rights and obligations, the system of government, the history and culture, their life and health, the ecological environment and the codes of conduct, and they should also develop their ability to communicate and form proper views of life and value system. All this is similar to that in the West, but the specific aim and content of each phase are significantly different.

In China's traditional moral education, there are some problems with the aims and contents in various stages. For example, the educational aims are inconsistent with the contents, the system is not designed scientifically and there is no accurate internal logic and consistency between different stages. Besides, the educational aims and contents are not so suitable for the basic knowledge and mental maturity of the students at various stages. From the experience of other countries, civic education is mainly fulfilled in primary and high schools, which is just consistent with the age requirement based on the rights and obligations in each country. According to China's Constitution, a person will be a responsible citizen just before or after he graduates from high school. And most contents of civic education should be completed before students graduate from high school. However, the legal knowledge and relevant social ethics necessary for citizens to obtain citizenship couldn't be taught to the students on schedule. Therefore, in our view, at least the major contents of the course Ideological and Moral Cultivation and Legal Basis arranged for university students should be taught to the senior high school students aged 18 years.

After basic education, the period of higher education is the time when students learn professional knowledge and vocational skills. After this phase of study, university students with professional knowledge and skills will enter certain occupational groups of our society. In today's world, characterized by highly developed science and technology, global economic integration and fierce collision of political ideology and cultural values, China is continuing to push forward the process of reform and opening up in a positive manner. Under the circumstances, professionalism and globalization request that the extended civic education in university should mainly focus on learning legal rules and moral values in occupational areas, learning about the multi-cultural world and showing respect for different cultures. In higher education, civic education should be extended in the professional and technical field, enabling students to study rules of survival and to learn professional co-operation specifications. Considering the university students' knowledge reserves and mental maturity, the main aim of civic education should be to learn about industry regulations and social expectations of the industry, that is to say, students should be aware of their responsibility and mission, learn to make choices and decisions in a complex professional activities, develop behavior control and enhance the ability to think rationally.

We have known that in higher education in foreign countries, although the concept of civic education is not so stressed as in primary and high schools, the professional ethics education is indispensable for the students of most specialties, such as the specialties of medicine, law and engineering. And in many countries (like the United States), the qualification examinations contain the contents of professional regulations and ethics. Such courses should be considered as the extension of civic education in university, because this kind of learning also aims to make the educated smoothly integrate into the society so that they can satisfy the need of the special social life--- professional life. We believe that this is the very content of civic education that universities should have, and the contents of moral education in China we are now having only makes up for what the high school 
students have missed for civic education.

\section{Approaches to civic education in university}

The main task of civic education in university is not to understand social norms, but to determine correctly the consequences of behavior and select rationally the appropriate behavior in such a society with complex interest relationship, so the educational aim in university has been transferred to the value judgment and the ability to control the behavior. Then, the corresponding teaching methods should also be adjusted. At least, the methods of the knowledge-based passive learning and the lecture-based cramming no longer adapt to universities' educational aims and contents or the intellectual level of students.

Now that the university students are expected to independently judge right and wrong and carefully select their behavior in a complex social environment and the professional activities that other people can hardly understand, we must provide effective methods to enhance their behavioral competence. Case teaching is a widely used method in recent years, which enables students to feel the real-life atmosphere, to access the society tentatively and to learn to select their behavior. In addition, the subjectivity education should also be reflected in the methods. For example, students are expected to carry out group activities, program discussion and even debates. Students' intellectual activities can be mobilized when they participate in the classroom activities.

Social practice is also an effective method for students to participate in social life. Such social practice is often controlled by teachers and the level of participation in social practice is not deep, so students can see the consequences of their behavior but will not cause adverse social consequences because of some naive behavior. Although social practice must be carried out under some given conditions with the support of certain social resources and funding, yet the effect is excellent. University students have been basically mentally mature and regarded as citizens with independent personality in society. Therefore, in order to adapt to the complex social environment, university students should think rationally the problems about themselves and the society within the scope of their own community, country and even the whole world, restrain their own behavior with the code of conduct accepted by the entire society, enhance their own judgment ability in the era of the conflict and convergence of eastern and western values as well as traditional and modern values, and at the same time actively participate in political activities and social life to understand the core principles of democracy and the government's operating mechanism, to cultivate the spirit of unity and cooperation and to establish good interpersonal relationship.

At present, according to Views on the Overall Planning of Moral Education System in Schools ${ }^{9}$ issued by the Ministry of Education in 2005, all the universities in China must offer the following courses: "Basic Principles of Marxism," "An Introduction to Mao Zedong Thought, Deng Xiaoping Theory and the Significant Thought of Three Representatives ", "Outline of Modern Chinese History" and " Situation and Policy ". All these are mainly informative courses and the traditional teaching methods are still employed in class, so the content of the courses is obviously not suited to the intellectual level of students and the teaching methods need to be improved.

\section{Conclusion}

In this paper, after we get to know and analyze the essence of "civic education" and compare civic education with the traditional moral education, we put forward the following points of view: Different levels of the national education should have different civic education aims adapting to the conditions of students of different levels; the task of civic education in universities, fundamentally different from that of primary and high schools, is to establish citizens' subjective personality, which focuses on the students' ability of judgment about right and wrong and the control of their behavior; we should make up for the missing content about professional values and occupation criteria in order to accommodate the students to the highly specialized skill-based society. In the paper we also question the current methodological issues and then put forward some teaching methods adapting to civic education aims.

\section{References}

Cihai. (1980). Shanghai Lexicographic Publishing House, p. 279.

Ibid. p. 281.

$\mathrm{Hu}$, Jintao. (2007). Full text of $\mathrm{Hu}$ Jintao's report at 17th Party Congress (6) [Online] Available: http://english.people.com.cn/90001/90776/90785/6290143.html (January 30, 2010).

Kathleen Knight-Abowitz. (2009). Citizenship Education, In Eugene F. Provenzo Jr. (Eds.). Encyclopedia of the social and cultural foundations of education (pp.128-129) .CA: SAGE Publications, Inc.

Li, Ping \& Zhong, MingHua. (2002). Civic Education --- Historic Transformation of the Traditional Moral 
Education. Education Research, 10, 66-69.

Monalisa M. Mullins. (2008). Civic Education, In F. Clark Power, et al. (Eds.), Moral education: a handbook (p.79). Westport, CT: Praeger Publishers.

[Online] Available: http://www.moe.edu.cn/edoas/website18/30/info13730.htm (January 30, 2010).

Tang, Kejun. (2008). Comparative Civic Education. Beijing: China Social Sciences Press, pp.62-64.

Ibid. pp. 93-98. 